Trakya Eğitim Dergisi

Cilt 12, Sayı 1

Ocak 2022, 193-202

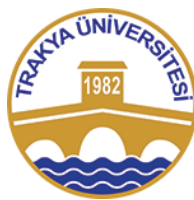

ISSN: 2630-6301

Doi: $10.24315 /$ tred. 884775

Araştırma Makalesi
Trakya Journal of Education

Volume 12, Issue 1

January 2022, 193-202

\title{
OKUL ÖNCESİ DÖNEM ÇOCUKLARINDA AKRANLAR TARAFINDAN DIŞLANMANIN YORDAYICILARI
}

\section{PREDICTORS OF PEER REJECTION AMONG PRESCHOOL CHILDRENS}

\author{
Selen Demirtaş-Zorbaz ${ }^{1}$, İnan Arıkan ${ }^{2}$ \\ Sinem Gül ${ }^{3}$
}

ÖZ: Bu çalışmada okul öncesi dönem çocuklarının akranları tarafından dışlanmasında prososyal davranışların, öğretmenle kurulan ilişkinin ve akranlara karşı saldırgan davranışların rolünün incelenmesi amaçlanmıştır. Bu amaç doğrultusunda okul öncesi eğitime devam eden 249 çocuk için 25 öğretmenden bilgi toplanmıştır. Çalışmanın hipotezlerini test etmek amacıyla gerçekleştirilen çoklu regresyon analizi sonuçlarına göre öğretmenle olan yakınlık ve akranlarla saldırgan davranışlar akranlar tarafindan dışlanmanın yordayıcısı olarak bulunurken; öğretmenle olan çatışma ve prososyal davranışlar yordayıcı olarak bulunmamıştır. Çalışmanın bulguları beraber değerlendirildiğinde okul öncesi dönem çocuklarıyla çalışan ruh sağlığı uzmanlarının akranlar tarafından dışlanmayı önlemek için çocuklara sosyal beceri öğretimi ve öğretmenle etkili iletişim kurma gibi konulara odaklanmaları önerilebilir.

Anahtar sözcükler: akranlar tarafından dıșlanma, prososyal davranışlar, öğretmenle yakınlık, öğretmenle çatışma, saldırgan davranışlar

\begin{abstract}
In this study, it was aimed to examine role of prosocial behaviors, teacher-student relationship and aggression on excluded by peers among preschool children. For this aim, data was collected from 25 preschool teachers for 249 children. Based on the results of multiple regression analysis performed to test the hypotheses of the study, it was seen closeness to the teacher and aggression towards peers were predict excluded by peers significantly whereas conflict with teacher and prosocial behavior were not. When the findings of the study are evaluated together, it may be suggested that mental health professionals working with preschool children could focus on subjects such as teaching children social skills and establishing effective communication with teachers in order to avoid being excluded by their peers.
\end{abstract}

Keywords: Peer rejection, prosocial behavior, closeness to teacher, conflict with teacher, aggressive behaviors toward peers.

\section{Bu makaleye atıf vermek için:}

Demirtaş-Zorbaz, S., Arıkan, İ. ve Gül, S. (2022). Okul öncesi dönem çocuklarinda akranlar tarafindan dışlanmanin yordayıcıları, Trakya Ĕgitim Dergisi, 12(1), ss. 193-202

\section{Cite this article as:}

Demirtaş-Zorbaz, S., Arıkan, İ. \& Gül, S. (2022). Predictors of peer rejection among preschool childrens, Trakya Journal of Education, 12(1), pp. 193-202

\footnotetext{
${ }^{1}$ Doç. Dr., Ankara Üniversitesi Rehberlik ve Psikolojik Danışma Anabilim Dalı, Ankara / Türkiye e-mail: selenpdr@gmail.com ORCID: 0000-0003-0040-9095

2 Psikolojik danışman, Karşıyaka Vilayetler Hizmet Birliği Anaokulu, Ordu / Türkiye e-mail: inanarikan62@gmail.com ORCID: 0000-0002-6037-5539

3 Psikolojik danışman, Şehit Ali Şahin Odabaşı İlkokulu, Ordu / Türkiye, e-mail: sinemergun06@ gmail.com ORCID: 0000-00034200-3982
} 


\section{EXTENDED ABSTRACT}

\section{Introduction}

The relationship that preschool children establish with their peers will affect the child's future life in many ways, and these experiences may affect the whole society in the triangle of child, school and family. Since preschool institutions are places where children experience social roles outside of the family and acquire the necessary social skills to live in society, the relationship established with peers can come to the fore in this period (Solak Arabacı \& Demircioğlu, 2019). Communication between children and their peers in this period can help them develop problem-solving and coping skills (Dinçer et al., 2019).

Although the importance of peer relationships is acknowledged, not all children are able to maintain their peer relationships properly in the preschool period and they may experience failure in this social role by being excluded by their peers. Researchers have focused on vhich characteristics of the children or the context they are in lead to exclusion by peers and the later effect of exclusion by peers in the early period. When the literature is reviewed, it is seen that there are many studies on protective and risk factors in excluding children by their peers. For example; emotion regulation (Godleski et al., 2015) and prosocial behaviors $($ Sal1, 2014) can be considered as protective factors. Among the risk factors, characteristics such as exposure to maltreatment (Bolger \& Patterson, 2001), difficulties in the recipient language (Mentinget al., 2011), insecure attachment (Wood et al., 2004) can be counted. Therefore, it can be said that in addition to the individual characteristics of children, systems such as teachers and peers with whom they establish relationships in school sometimes appear as protective and sometimes as a risk factor. In this study, prosocial behaviors handled as an indicator of the social / behavioral competence level of children within the scope of protective factors and closeness with the teacher as an indicator of their relationship with the teacher were considered, and as a risk factor, the conflict with the teacher and the variables of aggressive behaviors towards peers as an indicator of peer relations were excluded by peers.

When the literature on peer relationships of preschool children is considered, it is seen that problems with peers in this period also cause problems in the later stages of the children. Therefore, the importance of early interventions in developing healthy peer relationships once again comes to the fore. For the planning of such interventions, it is considered important to determine the predictors of exclusion by peers in the preschool period. Based on this, the aim of this study is to reveal whether the exclusion of preschool children by their peers is predicted by the closeness established with the teacher, conflict with the teacher, prosocial behaviors and aggressive behaviors. Revealing the relationships between these variables can help mental health professionals working with preschool children to plan their work and develop preventive and intervention programs.

\section{Method}

In this research, data were collected from 25 female teachers for children in four different preschool institutions in the central district of a metropolitan city in the fall period of 2019-2020. The students constitute a total of 249 children, 123 (49.4\%) girls and 126 (50.6\%) boys. Child Behavior Scale, TeacherStudent Relationship Scale and Personal Information Form were used as data collection tools in the study. SPSS 22 was used to analyze the data within the scope of the research. Descriptive statistics were obtained for each variable in the study. In line with the purpose of the study, multiple linear regression analysis was conducted to determine the predictors of exclusion by peers. In this study, the predictive variables were closeness with the teacher, conflict with the teacher, aggressive behaviors with peers and prosocial behaviors with peers, and the predicted variable was the excluded by the peers. In order to perform multiple linear regression analysis, some assumptions should be examined: linearity, normality, extreme values, multiple connectivity and autocorrelation (Tabachnick \& Fidell, 2007). All assumptions were met based on the given criteria.

\section{Findings}

As a result of the multiple regression analysis conducted to reveal the predictors of exclusion of preschool children by their peers, it was seen that the closeness with the teacher and aggressive behaviors with the peers significantly predicted the exclusion by the peers. $\left(\mathrm{F}_{(4-236)}=42.43 \mathrm{p}<.05\right)$. According to the standardized regression coefficients, the order of closeness to the teacher and the order of importance of aggressive behavior with peers on the predicted variable is aggression $(\beta=.566)$ and closeness established with the teacher $(=-.152)$. Considering the aspects of the relationships, it is seen that the closeness with the teacher predicts negatively and aggression positively predicts exclusion by peers. Predictive variables together explain $42 \%$ of the change in exclusion by their peers. 


\section{Discussion and Conclusion}

Based on the results of the study, while closeness with teachers and aggressive behaviors with peers were found to be predictors of exclusion by peers, conflict with the teacher and prosocial behaviors were not found to have a predictive effect on peer exclusion. When looking at the order of the predictor variables, it is seen that aggressive behavior towards peers is the most important predictor of exclusion by peers. This finding is a parallel finding with other studies in the literature that suggest a relationship between aggressive behaviors and peer relationships (Arnold, et al., 1999; Erol \& Gülay-Ogelman, 2020; Sal1, 2014; Wang et al., 2019; Wood et al., 2002). Longitudinal studies on aggressive behaviors and peer exclusion (Olson, 1992) reveal that there is a reciprocal relationship between the two, however, it is seen that more aggression leads to peer exclusion in the preschool period (Arnold et al., 1999; Wood et al., 2002).

Another variable that predicts exclusion by peers is the closeness with the teacher. This finding is a parallel finding with studies showing that the relationship established with the teacher has an effect on peer relationships (Chang et al., 2004; Demol, et al., 2020; Hughes, et al., 2006; Mercer \& DeRosier, 2008). One of the qualities that teachers should have is to establish a warm and close relationship with children (Dağlığlu, 2014). At the same time, preschool children especially value their teachers and can take them as role models. Therefore, students with whom the teacher behaves closely and establishes positive relationships in the classroom can also be popular with other students in the classroom.

\section{Gíriș}

Okul öncesi dönemdeki çocukların akranlarıyla kurdukları ilişki çocuğun ilerleyen dönemdeki yaşantısını birçok yönden etkileyecek olup, bu yaşantılar çocuk, okul ve aile üçgeninde tüm toplumu etkileyebilecektir. Okul öncesi kurumlar, çocukların aile dışında sosyal rolleri deneyimlediği ve toplumda yaşamak için gerekli sosyal becerileri kazandığı yerler oldukları için akranlarla kurulan ilişki bu dönemde daha da ön plana çıkabilmektedir (Solak Arabacı ve Demircioğlu, 2019). Bu dönemde çocukların akranlarıyla kurdukları iletişim onların problemleri çözme ve başetme becerileri geliştirmelerine destek olabilmektedir (Dinçer vd., 2019).

Akran ilişkilerinin önemi kabul edilmekle beraber her çocuk okul öncesi dönemde akran ilişkilerini sağlıklı olarak yürütülememekte ve akranları tarafından dışlanarak aile dışında deneyimledikleri bu toplumsal rolde başarısızlık yaşayabilmektedirler. Çocukların ya da içinde bulundukları bağlamın hangi özelliklerinin akranlar tarafından dışlanmaya yol açtığı ve erken dönemde yaşanan akranlar tarafından dışlanmanın ilerleyen zamanlardaki etkisi araştırmacıların yöneldiği konulardan biri olmuştur; Trentacosta ve Shaw (2009) yapmış oldukları boylamsal çalışmada erken dönemde kullanılan öz-düzenleme stratejilerinin akranlar tarafından dışlanmayı doğrudan etkilediğini ortaya koyarken ortaokul dönemindeki akranlar tarafından dışlanmanın ergenlik döneminde antisosyal davranışların yordayıcısı olduğunu belirtmektedirler. Bununla beraber akranlar tarafından dışlanmanın iliş̧kisel mağduriyetin yordayıcısı olduğu (Godleski vd., 2015), okula uyumu etkilediği (Buhs ve Ladd, 2001; Coie vd., 1992), kortizol seviyesini arttırdığ 1 da (Gunnar vd., 2003) bilinmektedir. Okul öncesi dönemde akranları tarafindan dışlanan çocukların ilerleyen dönemlerde hem biyolojik hem de psikolojik olarak risk altında oldukları bahsedilen çalışmalara istinaden söylenebilir. Bu nedenle okul öncesi dönemde akranlar tarafindan dışlanmayı etkileyen faktörleri ortaya koymak yapılacak önleyici çalışmalara yol göstermesi bakımından önemlidir.

Literatüre bakıldığında çocukların akranlar tarafından dışlanmasında koruyucu ve risk faktörlerine ilişkin birçok çalışma olduğu görülmektedir. Duygu düzenleme (Godleski vd., 2015) ve prososyal davranışlar (Sal1, 2014) koruyucu faktörler olarak bu hususta ele alınabilir. Risk faktörlerinde ise kötü muameleye maruz kalma (Bolger ve Patterson, 2001), alıcı dilde yaşanan güçlükler (Menting vd., 2011), güvensiz bağlanma (Wood vd., 2004) gibi özellikler sayılabilmektedir. Dolayısıyla çocukların bireysel özelliklerinin yanı sıra okul içinde ilişki kurdukları öğretmen ve akranlar gibi sistemlerin de kimi zaman koruyucu kimi zaman risk faktörü olarak ortaya çıktığı söylenebilir. Bu çalışmada koruyucu faktörler kapsamında çocukların sosyal / davranışsal yeterlik düzeyinin bir göstergesi olarak prososyal davranışlar, öğretmenle ilişkilerinin göstergesi olarak öğretmenle yakınlık değişkenleri ele alınmış ve risk faktörü olarak ise öğretmenle olan çatışma ve akran ilişkilerinin bir göstergesi olarak akranlara karşı saldırgan davranışlar değişkenlerinin akranlar tarafından dışlanmayı ne kadar yordadığı ele alınmıştır. 


\section{Akranlar Tarafından Dışlanma ve Prososyal Davranışlar}

Akranlar tarafından dışlanmanın bireysel düzeyde koruyucu bir faktörü olabilecek prososyal davranışlar, olumlu sosyal davranışlar (Uzmen ve Mağden, 2002) olarak tanımlanmaktadır. Literatüre bakıldığında prososyal davranış gösterme ile akran desteği arasında ilişki bulunduğu görülmektedir (Sebanc, 2003). Diğer bir ifade ile prososyal davranış gösteren çocuklar akranları tarafından daha çok kabul edilebilmektedirler. Aynı zamanda sosyal ilişkilerde sağlıksız olarak kabul edilen sosyal olarak içe çekilme (Wood vd., 2002) gibi davranışların akranlar tarafından dışlanma ile ilişkili olduğu ortaya konmuştur. Dahası, prososyal davranışlar ile akran kabulu arasında pozitif ilişki (Wang vd., 2019) bulunmaktadır. Genel anlamda çocuğun prososyal davranışları akranlarıyla kuracağı ilişkisinin yönünde belirleyici olabilmektedir (Gülay, 2009). Prososyal davranış gösteren çocuklar akranlarıyla daha sağlıklı ilişki kurabilirken prososyal davranış göstermeyen çocukların daha sağlıksız akran ilişkilerine sahip olabileceği söylenebilir.

Prososyal davranışlar çocukların yalnızca arkadaşlık ilişkilerine ya da akranları tarafından dışlanmasına etki etmekle kalmamakta aynı zamanda çocuğun akranları tarafından çeşitli şiddet davranışlarına maruz kalmasına da etki edebildiği; prososyal davranışların kurban yerine zorba olmayı yordadığı (Çalık vd., 2009), prososyal davranışlar ile akran şiddetine maruz kalma arasında negatif ilişki (Salı, 2014) olduğu görülmektedir. Buradan hareketle okul öncesi dönem çocuklarının sahip oldukları prososyal davranışların akranlar tarafından dışlanmalarında koruyucu bir faktör olabileceği ve prososyal davranış gösteren çocukların akranları tarafından dışlanmalarının daha düşük olabileceği düşünülmektedir.

\section{Akranlar Tarafından Dışlanma ve Öğretmen - Öğrenci İlişkisi}

Okul öncesi dönemde ebeveynlerden sonra çocukların ilişki kurdukları yetişkinlerin başında öğretmenler gelmektedir. Öğretmenlerin okul öncesi dönem çocuklarının üzerinde, aileden sonra en büyük rol modellerinden biri olacağı düşünülmektedir. Literatürdeki çalışmalara bakıldığında, sınıf içinde çocukların birbirlerine karşı olan olumsuz tutumlarında öğretmenlerin sınıf yönetimi becerilerinin etkisine odaklanıldığı görülmektedir. Gülay-Ogelman ve Ersan (2014) öğretmenlerin kullandıkları sınıf yönetim stratejilerinin akranlar tarafindan dişlanmayı etkilemediği ancak çocukların prososyal davranış göstermesinde etkili olduğu ortaya koymuşlardır. Aynı zamanda öğrenci merkezli öğrenme uygulamalarının akranlar tarafından dışlanmayı azalttığı da (Donohue vd., 2003) bilinmektedir. Bununla birlikte öğretmenler sınıf içinde birbirine karşı zorbaca davranış gösteren öğrencilerle baş etmede farklı yöntemler kullanabilmektedirler. Örneğin; zorbalık içeren bir davranışla karşılaştıklarında çocuk ile davranışı hakkında konuşmakta; söz konusu davranışları önlemek için ise görsel olarak kuralları anlatma gibi yöntemlere başvurabilmektedirler (Yalçıntaş-Sezgin, 2018).

Sınıf yönetim stratejilerinin yanı sıra akranlar arası ilişkilerin düzenlenmesinde öğretmenlerin öğrencileriyle kurduğu ilişkinin de önemli olabileceği düşünülmektedir. Aileden ayrılma ile birlikte bulunduğu ortama güven duyabilmek için öğretmeni ile güvenli bağlanma yaşantısı gerçekleştirmeye çalışan çocukların bu bağlanmayı gerçekleştirebilmesi onların okula uyumlarını kolaylaştırabilmektedir (Demir ve Köse, 2016). Araştırmalar (Mercer ve DeRosier, 2008) öğretmenlerin tercih ettiği öğrenci olmak ile akranlar tarafından dışlanma arasında ilişki olduğunu öne sürmektedirler. Aynı zamanda öğretmen öğrenci desteğinin (Hughes vd., 2006) ve öğretmenin öğrenciden hoşlanmasının (Chang vd., 2004) akranlar tarafından kabulu arttırdığı ve destekleyici öğretmen-öğrenci ilişkilerinin akranlar tarafından kurbanlaştırılmayı azalttığı (Demol vd., 2020) ortaya konmuştur. Diğer bir ifade ile öğretmenleri ile sıcak bir ilişki kuran çocukların akranları tarafından kabul edilme olasılıkları artarken tam tersi olarak öğretmeniyle çatışma yaşayan çocukların ise akran ilişkilerinin olumsuz etkilenebileceği düşünülmektedir. Buradan hareketle bu çalışmada öğretmenle yakınlık koruyucu bir faktör olarak ele alınırken; öğretmenle çatışma bir risk faktörü olarak ele alınmıştır.

\section{Akranlar Tarafından Dışlanma ve Dışsallaştırma Sorunları}

Okul öncesi dönemde sosyal hayatı ve akranlar tarafindan dışlanmayı etkileyebilecek diğer bir faktör de çocukların gösterdiği çeşitli dışsallaştırma sorunları olabilmektedir. Literatüre bakıldığında dışsallaştırma sorunlarından saldırgan davranışların ön plana çıktığı görülmektedir. Çocukların arkadaşlık ilişkilerinde sosyal olmayan problem çözme yöntemi olarak şiddeti seçmesi saldırganlık olarak adlandırılabilir (Yalçıntaş-Sezgin, 2018). Bu yöntemin seçilmesi çocuğun akran grubu tarafindan reddedilmesine, çocuğun yalnızlaştırılmasına ve prososyal davranışları göstermesinde gerilemelere sebep olduğu gözlemlenmiştir (Dinçer vd., 2019). Erol ve Gülay-Ogelman (2020) tarafından yapılan bir çalışmada da saldırgan özellikler gösteren okul öncesi dönem çocuklarının akranları tarafından daha az sevildiği görülmüştür. Salı (2014) ise çalışmasında saldırgan davranışlar ile akran şiddetine maruz kalma arasında ilişki olduğunu ortaya 
koymuştur. Aynı zamanda saldırgan davranışlar akran kabulünü azaltmaktadır (Wang vd., 2019). Bununla birlikte çocukluk dönemindeki saldırgan davranışların ve akranlar tarafından dışlanmanın ergenlikteki çeşitli bozuklukları yordadığı (Coie, vd., 1992; Coie vd., 1995) bilinmektedir. Yapılan boylamsal çalışmalar ise (Olson, 1992) saldırgan olarak tanımlanan çocukların dönem başında dışlandıklarını ve bu dışlanmanın yıl sonunda da devam ettiğini ortaya koymakla beraber dışlanan çocukların da daha fazla saldırgan özellikler gösterdikleri görülmüştür. Ayrıca saldırgan davranışların, kötü muameleye maruz kalma ile akranlar tarafından dışlanma (Bolger ve Patterson, 2001) ve güvensiz bağlanma ile akranlar tarafından dışlanma (Wood vd., 2004) arasında aracı rolü olduğu ortaya konmuştur.

Literatüre bakıldığında; akranlar tarafından dışlanma saldırgan davranışlara yol açabileceği gibi, saldırgan davranışları olan çocukların da akranları tarafından dışlandığı söylenebilir (örn., Chen vd., 2011). Aynı zamanda bu ilişkiyi etkileyen farklı faktörlerin varlığından da söz edilmektedir. Bununla birlikte saldırganlığın okul öncesi dönem çocuklarında akranlar tarafından dışlanma ile ilişkili olduğu (Arnold vd., 1999; Wood vd., 2002) ancak ilkokulun son dönemlerinde saldırgan davranışların tam tersi akranlar tarafından dışlanmayı azalttığı (Sandstorm ve Coie, 1999) görülmektedir. Söz konusu çelişkili bulgulara bakıldığında akranlara karşı gösterilen saldırgan davranışlar ile akranlar tarafından dışlanma arasındaki ilişkinin niteliğini anlamak için daha fazla araştırmaya ihtiyaç olduğu görülmektedir.

\section{Çalışmanın Amacı}

Okul öncesi dönem çocuklarının akran ilişkileri ile ilgili literatür ele alındığında bu dönemde akranlarla ilgili yaşanan problemlerin çocukların ilerleyen dönemlerinde de soruna yol açtığ görülmektedir. Dolayısıyla sağlıklı akran ilişkileri geliştirmede erken dönem müdahalelerinin önemi bir kez daha ön plana çıkmaktadır. Bu tür müdahalelerin planlanması için okul öncesi dönemde akranlar tarafından dışlanmanın yordayıcılarının ortaya konması önemli görülmektedir. Buradan hareketle bu çalışmanın amacı okul öncesi dönem çocuklarının akranlar tarafından dışlanmasının öğretmenle kurulan yakınlık, öğretmenle çatışma, prososyal davranışlar ve saldırgan davranışlar tarafından yordanıp yordanmadığının ortaya konmasıdır. $\mathrm{Bu}$ amaç doğrultusunda, bu araştırmada "okul öncesi çocuklarının öğretmenle kurulan yakınlık, öğretmenle çatışma, prososyal davranışlar ve saldırgan davranışlarının değişkenleri akranlar tarafından dışlanmanın yordayıcısı mıdır?" sorusuna yanıt aranmıştır. Söz konusu değişkenler arasındaki ilişkilerin ortaya konulması okul öncesi dönem çocuklarıyla çalışan ruh sağlı̆̆ uzmanlarının çalışmalarını planlaması, önleyici ve müdahale edici programlar geliştirmesine yardımcı olabilecektir.

\section{YÖNTEM}

\section{Araştırmanın Modeli}

$\mathrm{Bu}$ araştırmada okul öncesi dönem çocuklarının akranlar tarafından dışlanmasının öğretmenle kurulan yakınlık, öğretmenle çatışma, prososyal davranışlar ve saldırgan davranışlar arasındaki ilişkinin belirlenmeye amaçlanmıştır. Araştırma, değişkenler arasındaki ilişkinin müdahale edilmeden incelendiği ilişkisel araştırma (Büyüköztürk vd., 2015) modeline sahiptir.

\section{Çalışma Grubu}

$\mathrm{Bu}$ araştırmanın çalışma grubunu 2019 - 2020 güz döneminde kuzeydoğuda bulunan bir büyük şehrin merkez ilçesinde yer alan 123'ü (\%49.4) kız ve 126'sı (\%50.6) erkek olmak üzere toplam 249 çocuk oluşturmaktadır. Öğrencilerin çeşitli özellikleri hakkında bilgi almak için hazırlanan ölçme araçları seti dört farklı okul öncesi kurumunda görev yapmakta olan 25 kadın öğretmen tarafından doldurulmuştur.

\section{Veri Toplama Aracı}

Araştırmada veri toplama aracı olarak, Çocuk Davranış Ölçeği, Öğretmen-Öğrenci İlişki Ölçeği ve Kişisel Bilgi Formu kullanılmıştır.

Çocuk Davranış Ölçeği: Ladd ve Profilet (1996) tarafından geliştirilen Çocuk Davranış Ölçeği'nin Türkiye'ye uyarlama çalışması (ÇDÖ) Ergene vd., (2018) tarafından yapılmıştır. Ölçek öğretmenler tarafından doldurulmakta ve öğretmenlerin öğrencilerinin davranış sorunlarını ve arkadaşlık ilişkilerini ölçek maddelerine göre değerlendirmektedirler. Ölçekte toplam 59 madde bulunmaktadır, ancak bu maddelerin 24 tanesi yanlılığ önlemek amaciyla dolgu madde olarak kullanılmaktadır. 35 madde ise akranlarla "saldırgan davranışlar, hiperaktivite, akranlarla asosyal ilişki, kaygı-korku duyma, akranlarla 
prososyal ilişki ve akranlar tarafından dışlanma" olmak üzere altı boyutu oluşturmaktadır (Ladd, 2010). Ölçeğin orijinal formunda güvenirlik katsayıları akranlara saldırgan boyutunda .81 ile .93 ; hiperaktivitedağınıklık (HD) boyutunda .83 ile .95 ; akranlarla asosyal ilişki (AAİ) boyutunda .81 ile .91 ; kayg1-korku (KK) boyutunda .65 ile .75; akranlarla prososyal ilişki (API) boyutunda .76 ile .90 ve akranlar tarafindan dışlanma (AD) boyutunda .85 ile .94 arasında elde edilmiştir (Ladd, 2010). Türkiye uyarlama çalışmasında ise akranlarla saldırgan davranışlar .92, hiperaktivite .78, akranlarla asosyal ilişki .86, kaygı-korku duyma .74, akranlarla prososyal ilişki .86 ve akranlar tarafından dışlanma .92 iç tutarlılık katsayısına sahiptir (Ergene vd., 2018). Bu araştırmada ölçeğin boyutlarından akranlarla saldırgan davranışlar, akranlarla prososyal ilişki ve akranlar tarafından dışlanma boyutları kullanılmıştır. Bu çalışmada boyutların iç tutarlı1ık güvenirlik katsayısı için hesaplanan Cronbach's Alpha değeri akranlarla saldırgan davranışlar boyutu .86 , akranlarla prososyal ilişki .85 ve akranlar tarafından dışlanma .84 olarak bulunmuştur.

Öğretmen-Öğrenci İlişki Ölçeği: Pianta ve Nimetz (1991) tarafından anaokulu öğretmenleri üzerinde geliştirilen ve Pianta (2001) tarafından son hali verilen Öğretmen-öğrenci ilişki ölçeğinin uyarlaması Demirtaş-Zorbaz vd., (2016) tarafından yapılmıştır. Ölçeğin üç alt boyutu bulunmaktadır ve çatışma boyutunda 12 madde; yakınlık boyutunda 11 madde ve bağımlılık boyutunda ise beş madde olmak üzere toplam 28 maddeden oluşmaktadır. Öğretmenler tarafindan doldurulan ölçekte öğretmenlerden öğrencileriyle olan ilişkilerinin değerlendirilmesi istenmektedir. Ölçeğin son halinde iç tutarlılık anlamındaki güvenirlik katsayısı için hesaplanan Cronbach's Alpha değeri çatışma alt boyutu için .92; yakınlık alt boyutu için .86; alt bağl1lık boyutu için .64 ve tüm ölçek için .89 olarak hesaplanmıştır (Pianta, 2001). Ancak Türkiye uyarlama çalışmasında bağımlılık boyutu ölçekten çıkarılarak çatışma ve yakınlık alt boyutları için iç tutarlılık anlamında güvenirlik katsayıları elde edilmiştir. Yakınlık boyutu için Cronbach Alfa katsayısı .83 ve çatışma boyutu için Cronbach Alfa katsayısı .86 olarak bulunmuştur (Demirtaş-Zorbaz vd., 2016). Bu çalışmada iç tutarlılık güvenirlik katsayısı için hesaplanan Cronbach's Alpha değeri yakınlık boyutu için .89 ve çatışma boyutu için .83 olarak bulunmuştur.

Kişisel Bilgi Formu: Çalışma kapsamında araştırmacılar tarafından geliştirilen kişisel bilgi formu okul adı, öğrencilerin cinsiyetleri ve öğretmenin cinsiyeti olmak üzere üç sorudan oluşmaktadır.

\section{Verilerin Toplanması ve Analizi:}

Çalışma için gerekli izinler alındıktan sonra okulların rehberlik servisleriyle iletişime geçilmiş ve çalışmanın amacı hakkında bilgi verilmiştir. Daha sonra araştırmacılar çalışmanın yapılacağı okula giderek öğretmenleri çalışmanın amacı ve ölçek setlerinin nasıl doldurulacağı hakkında bilgilendirmiş, çalışmaya katılacak öğretmenler onam formu doldurulmuştur. Öğretmenler sınıflarındaki öğrenci listesinden rastgele 10 çocuk belirlemiş ve çocukların ebeveynlerinin onayını aldıktan sonra ölçek setlerini doldurmuşlardır. Ölçeklerin doldurulması yaklaşık bir hafta sürmüştür. Veriler araştırmacılar tarafından SPSS'e aktarılmıştır.

Araştırma kapsamındaki verilerin analizinde SPSS 22 programı kullanılmıştır. Araştırmadaki her bir değişken için betimsel istatistikler elde edilmiştir. Çalışmanın amacı doğrultusunda akranlar tarafından dışlanmanın yordayıcılarını belirlemek amacıyla çoklu doğrusal regresyon analizi yapılmıştır. $\mathrm{Bu}$ araştırmada yordayıcı değişkenler öğretmenle kurulan yakınlık, öğretmenle olan çatışma, akranlarla saldırgan davranışlar ve akranlarla prososyal davranışlar, yordanan değişken ise akranlar tarafindan dışlanma değişkeni olmuştur. Çoklu doğrusal regresyon analizinin yapılabilmesi için doğrusallık, normallik, uç değerler, çoklu bağlantılılık ve otokorelasyon varsayımların incelenmesi gerekmektedir (Tabachnick ve Fidell, 2007).

Doğrusallık varsayımı için bağımlı ve bağımsız değişkenler arasında saçılma diagramları incelenmiş ve değişkenler arasında doğrusal bir ilişki olduğu görülmüştür. Tek değişkenli uç değerler için değişkenler standart puanlara dönüştürülmüş ve $\mathrm{z}=+/-3.29$ (Tabachnick ve Fidell, 2007, ss. 73) aralığının dişındakiler uç değer olarak kabul edilmiştir. Çok değişkenli uç değerler için ise Mahalanobis uzaklığı hesaplanmış ve $\mathrm{p}<0.001$ düzeyinde anlamlı olanlar çok değişkenli uç değer olarak kabul edilmiştir. Uç değer olmaları nedeniyle toplam 7 çocuk veriden çıkarılmıştır. Çoklu bağlantılılık için varyans büyütme faktörü (VIF), durum indeksi (CI) ve tolerans değeri incelenmiştir. VIF değerinin 10'dan küçük, durum indeksinin 30'dan küçük ve tolerans değerinin 0.2 'den büyük olduğu bulunmuştur. Bu durum çoklu bağlantı probleminin olmadığını göstermektedir. Diğer bir varsayım olan otokorelasyon için Durbin-Watson istatistiği 1.64 $(\mathrm{DW}<4)$ bulunmuş ve değişkenler arasında otokorelasyon olmadığı görülmüştür. 


\section{Araştırmanın Etik İzinleri}

Yapılan bu çalışmada araştırma etiği ilkeleri gözetilmiş olup gerekli etik kurul izinleri alınmıştır. Etik kurul izni kapsamında; Sosyal ve Beşeri Bilimler Araştırmaları Etik Kurulu, 27.01.2021 tarih ve 21 sayılı belge alınmıştır.

\section{BULGULAR}

Araştırmadaki yordayıcı değişken ve yordanan değişkenler arası korelasyon katsayıları ve değişkenlere ilişkin ortalama, sapma, basıklık-çarpıklık değerlerinden oluşan betimsel istatistikler Tablo 1'de yer almaktadir.

Tablo 1.

Değişkenlere ilişkin betimsel istatistikler ve değişkenler arası korelasyon katsayıları

\begin{tabular}{|c|c|c|c|c|c|c|c|c|c|c|}
\hline $\begin{array}{l}\text { Değişkenl } \\
\text { er }\end{array}$ & $\begin{array}{c}\text { yakınlı } \\
\text { k }\end{array}$ & $\begin{array}{c}\text { çatışm } \\
\text { a }\end{array}$ & $\begin{array}{l}\text { saldirga } \\
\mathrm{n}\end{array}$ & $\begin{array}{c}\text { dişlanm } \\
\text { a }\end{array}$ & $\begin{array}{c}\text { prososy } \\
\text { al }\end{array}$ & $\mathrm{N}$ & ort & SS & $\underset{\mathrm{k}}{\text { Çarpıklı }}$ & $\begin{array}{c}\text { Basikl1 } \\
\mathrm{k}\end{array}$ \\
\hline yakınlık & 1 & & & & & 241 & 45,44 & 6,06 & $-0,67$ & 0,61 \\
\hline catışma & , $376 * *$ & 1 & & & & 241 & 21,78 & 8,16 & 0,91 & 0,22 \\
\hline saldırgan & , $228 * *$ &, $498 * *$ & 1 & & & 241 & 8,55 & 2,1 & 1,67 & 2,34 \\
\hline dışlanma & , $291 * *$ &, $403 * *$ &, $625 * *$ & 1 & & 241 & 8,21 & 1,94 & 1,56 & 1,35 \\
\hline prososyal &, $642 * *$ & $\begin{array}{l}- \\
447 * *\end{array}$ &,$- 460 * *$ &,$- 363^{* *}$ & 1 & 241 & 16,24 & 3,26 & $-0,23$ & $-0,63$ \\
\hline
\end{tabular}

Tablo 1 incelendiğinde; dışlanma ile prososyal $(r=-.363 ; p<.01)$, yakınlık $(\mathrm{r}=-.291 ; p<.01)$, çatışma $(r=.403 ; p<.01)$ ve saldırganlık $(r=.625 ; p<.01)$ arasında anlamlı bir ilişki bulunmuştur. Akranlar tarafından dışlanmayı yordayan değişkenleri belirlemek amacıyla yapılan çoklu regresyon analizi sonuçları Tablo 2'de gösterilmiştir.

Tablo 2.

Akranlar tarafindan dışlanmanın yordanmasına ilişkin çoklu regresyon analizi sonuçları

\begin{tabular}{llllllll}
\hline $\begin{array}{l}\text { Yordayan } \\
\text { değişken }\end{array}$ & $B$ & Std. Hata & $\beta$ & $T$ & $p$ & Zero-order & Partial \\
\hline Sabit & 5,274 & 1,045 & & 5,046 & 0 & & \\
yakınlık & $-0,049$ & 0,021 & $-0,152$ & $-2,3$ & 0,022 & $-0,291$ & $-0,148$ \\
catışma & 0,018 & 0,014 & 0,077 & 1,267 & 0,206 & 0,403 & 0,082 \\
saldırgan & 0,523 & 0,056 & 0,566 & 9,279 & 0 & 0,625 & 0,517 \\
prososyal & 0,017 & 0,043 & 0,029 & 0,404 & 0,687 & $-0,363$ & 0,026 \\
\hline $\mathrm{R}=0.65 ; \mathrm{R}^{2}=0.42$ & & & & & &
\end{tabular}

Tabloya göre, okul öncesi dönem çocuklarının akranları tarafından dışlanmalarının yordayıcılarını ortaya koymak için yapılan çoklu regresyon analizi sonucunda, öğretmenle kurulan yakınlık ve akranlarla saldırgan davranışların akranlar tarafindan dışlanmayı anlamlı olarak yordadığı görülmüştür $\left(F_{(4-236)}=42.43\right.$ $p<.05)$. Standartlaştırılmış regresyon katsayılarına göre öğretmenle kurulan yakınlık ve akranlarla saldırgan davranışların yordanan değişken üzerindeki önem sırası, saldırganlık $(\beta=.566)$ ve öğretmenle kurulan yakınlık $(\beta=-.152)$ şeklindedir. İlişkilerin yönleri dikkate alındığında ise, öğretmenle kurulan yakınlığın negatif yönde ve saldırganlığın ise pozitif yönde akranları tarafından dışlanmayı yordadığı görülmektedir. Yordayacı değişkenler birlikte akranları tarafından dışlanmadaki değişimin \%42'sini açıklamaktadırlar. Diğer bir ifade ile öğretmenle yakın ilişkiler kuran öğrencilerin akranlar tarafından dışlanma olasılığı azalırken, saldırgan davranış gösteren öğrencilerin akranlar tarafından dışlanma riski oluşmaktadır. 


\section{TARTIŞMA, SONUÇ ve ÖNERILER}

Bu çalışmada okul öncesi dönem çocuklarının akranlar tarafindan dışlanmasında öğretmenle kurulan yakınlık, öğretmenle çatışma, prososyal davranışlar ve saldırgan davranışlarının yordayıcı rolü incelenmiştir. Çalışma sonuçlarına göre öğretmenle kurulan yakınlık ve akranlarla saldırgan davranışlar akranlar tarafından dışlanmanın yordayıcısı olarak bulunurken öğretmenle çatışma ve prososyal davranışların akranlar tarafından dışlanmada yordayıcı etkisi bulunmamıştır. Yordayıcı değişkenlerin sırasına bakıldığında akranlara karşı saldırgan davranış göstermenin akranlar tarafından dışlanmanın en önemli yordayıcısı olduğu görülmektedir. Bu bulgu saldırgan davranışlar ile akranlar ilişkileri arasında ilişki olduğunu öne süren literatürdeki diğer çalışmalarla (Arnold, vd., 1999; Erol ve Gülay-Ogelman, 2020; Sal1, 2014; Wang vd., 2019; Wood vd., 2002) benzer bir bulgudur. Saldırgan davranışlar ile akranlar tarafından dışlanma ile ilgili yapılan boylamsal çalışmalar (Olson, 1992) ikisi arasında karşılıklı ilişki olduğunu ortaya koymakla beraber okul öncesi dönemde daha çok saldırganlığın akranlar tarafından dışlanmaya yol açtığı (Arnold vd., 1999; Wood vd., 2002) görülmektedir. Okul öncesi dönem kendi içinde kuralları olan ve görece yapılandırılmış bir ortam olduğundan çocuğun karşılaştığı ilk formal kurum olabilmektedir. Bu nedenle çocuklar sahip oldukları saldırganlık gibi çeşitli davranışsal güçlükleri burada sergileyebilmekte ve bunun sonucu olarak sınıf içinde sosyal konumlarını belirleyebilmektedirler. Aile içinde tolere edilebilen bazı davranışlar akranları tarafından tolere edilemeyebilmekte ve bu da ilişkilerine zarar verebilmektedir. Dolayısıyla okul öncesi dönem çocuklarının saldırgan davranış gösteren akranlarıyla beraber olmak istememeleri ve onu dışlamaları beklenen bir durum olabilmektedir.

Akranlar tarafından dışlanmayı yordayan diğer bir değişken de öğretmenle kurulan yakınlıktır. Bu bulgu öğretmenle kurulan ilişkinin akranlarla ilişkilerine etkisi olduğunu gösteren çalışmalarla (Chang vd., 2004; Demol, vd., 2020; Hughes, vd., 2006; Mercer ve DeRosier, 2008) benzer bir bulgudur. Öğretmenlerin sahip olması gereken niteliklerden biri de çocuklarla sıcak ve yakın ilişki kurmaktır (Dağlığlu, 2014). Aynı zamanda okul öncesi dönem çocukları öğretmenlerine özellikle değer vermekte ve onu rol model alabilmektedirler. Dolayısıyla öğretmenin sınıf içerisinde yakın davrandığı ve olumlu ilişkiler kurduğu öğrenciler, sınıf içindeki diğer öğrenciler için de popüler olabilmektedir. Nitekim, Mercer ve DeRosier (2008) de öğretmenlerin tercih ettiği öğrenci olmak ile akranlar tarafından dışlanma arasında ilişki olduğunu ifade etmektedirler. Bununla birlikte Dereli (2016) öğretmenin sınıf ikliminde kullandığı olumlu davranışların öğrencilerin sosyal problem çözme becerilerine katkı sunabileceğine, öğretmenin problem yaşadığı öğrencilerin ise sınıf ikliminde akranları ile anlaşmazlıklar yaşayabileceğine işaret etmiştir. Dolayısıyla öğretmenin sınıf yönetme becerileri sınıfın iklimini etkileyebilmekte ve bu durumda akranlar arası sorunlar yaşanmasına yol açabilmektedir. Güder vd. (2018) de öğretmenlerin sınıf içerisinde akranlar arasında yaşanan problemlerin çözümüne katkı sunması, öğretmen tutumlarının öğrenci davranışlarına etkisinin önemi ve sınıf yönetiminde yetkinleştirilmesi amacıyla çeşitli eğitimlerle desteklenmesi gerektiğini ifade etmektedirler.

Çalışmanın bulguları beraber değerlendirildiğinde okul öncesi dönem çocuklarıyla çalışan ruh sağlığı uzmanlarının çocukların gösterdiği saldırganlık davranışlarına özellikle dikkat etmeleri ve ilerleyen zamanlarda bu davranışların akranları tarafından dışlanmalarına yol açmaması için dönem başında uygun sosyal davranış kazanmaları için çocuklarla çalışmalar yapmaları önerilebilir. Öğretmenle kurulan yakın ilişkinin akranlar tarafından dışlanmada koruyucu bir faktör olduğu göz önüne alındığında ise okul öncesi öğretmenlerine sınıf içinde çocuklarla kurdukları ilişkide yakınlığa önem vermeleri ve onların çocuklarla kurdukları ilişkinin kalitesinin çocukların akranları içindeki konumunu belirlediğinin farkında olmaları söylenebilir. Okul öncesi kurumlarında öğretmen - öğrenci ilişkilerini geliştirmeye yönelik çeşitli eğitim, etkinlik gibi aktiviteler gerçekleştirilebilir. Bununla birlikte bu çalışmada ele alınan değişkenler akranlar tarafından dışlanmanın \%42'sini açıklamıştır. Dolayısıyla akranlar tarafından dışlanmada etkili olan başka faktörlerin varlığının da göz önünde bulundurulması ve daha detaylı incelenmesi önerilebilir.

Literatüre katkısının yanı sıra bu çalışmanın bazı sınırlıkları bulunmaktadır. Öncelikle bu çalışma Türkiye'nin kuzeyinde bulunan bir büyükşehirde devlet okullarında gerçekleştirilmiştir. Dolayısıyla çalışma sadece benzer özelliklere sahip gruplara genellenebilir. Bununla birlikte bu çalışmada okul öncesi dönem çocuklarının özellikleri öğretmen gözlemlerine dayalı olarak alınmıştır. Gelecek araştırmalarda ebeveynlerin gözlemlerine de yer verilebilir. Aynı zamanda çalışmaya seçilen öğrenciler sınıf listesinden random olarak seçilmiştir. Gelecekteki araştırmacılar sınıf içinde hem dışlanan hem de dışlanmayan çocukları eşit şekilde örnekleme dahil ederek, karşılaştırmalı çalışmalar yapabilirler. 


\section{KAYNAKÇA}

Arnold, D. H., Homrok, S., Ortiz, C., \& Stowe, R. M. (1999). Direct observation of peer rejection acts and their temporal relation with aggressive acts. Early Childhood Research Quarterly, 14(2), 183-196.

Bolger, K. E., \& Patterson, C. J. (2001). Developmental pathways from child maltreatment to peer rejection. Child Development, 72(2), 549-568.

Buhs, E. S., \& Ladd, G. W. (2001). Peer rejection as antecedent of young children's school adjustment: An examination of mediating processes. Developmental Psychology, 37(4), 550.

Büyüköztürk. Ş., Kılıç-Çakmak, E., Akgün, Ö. E., Karadeniz, Ş. ve Demirel, F. (2015). Bilimsel araştırma yöntemleri. Pegem Akademi.

Chang, L., Liu, H., Wen, Z., Fung, K. Y., Wang, Y., \& Xu, Y. (2004). Mediating teacher liking and moderating authoritative teachering on chinese adolescents' perceptions of antisocial and prosocial behaviors. Journal of Educational Psychology, 96(2), 369.

Chen, C. C., McComas, J. J., Hartman, E., \& Symons, F. J. (2011). A prospective sequential analysis of the relation between physical aggression and peer rejection acts in a high-risk preschool sample. Early Education \& Development, 22(4), 574-592.

Coie, J. D., Lochman, J. E., Terry, R., \& Hyman, C. (1992). Predicting early adolescent disorder from childhood aggression and peer rejection. Journal of Consulting and Clinical psychology, 60(5), 783-792.

Coie, J., Terry, R., Lenox, K., Lochman, J., \& Hyman, C. (1995). Childhood peer rejection and aggression as predictors of stable patterns of adolescent disorder. Development and Psychopathology, 7(4), 697-713.

Çalık, T., Özbay, Y., Özer, A., Kurt, T., ve Kandemir, M. (2009). İlköğretim okulu öğrencilerinin zorbalık statülerinin okul iklimi, prososyal davranışlar, temel ihtiyaçlar ve cinsiyet değişkenlerine göre incelenmesi. Kuram ve Uygulamada Ĕ̈itim Yönetimi, 60(60), 555-576.

Dağlıoğlu, E. (2014). Erken çocukluk dönemi öğretmenin özellikleri (İ. Diken, Ed.). Erken Çocukluk Eğitimi, içinde (syf. 482 - 515). Pegem Akademi.

Demir, E. ve Köse, M. (2016). Öğretmenlerin rol modelliği hakkında öğretmen görüşleri. Akademik Bakış Dergisi, 53, 38-57.

Demirtaş-Zorbaz, S., Özer, A., Gençtanırım-Kurt, D. ve Ergene, T. (2016). Öğretmen - öğrenci ilişki ölçeği’nin (ööiö) uyarlanması. Ĕgitimde ve Psikolojide Ölçme ve Değerlendirme Dergisi, 7(2), 407-418.

Demol, K., Leflot, G., Verschueren, K., \& Colpin, H. (2020). Revealing the transactional associations among teacherchild relationships, peer rejection and peer victimization in early adolescence. Journal of Youth and Adolescence, 49(11), 2311-2326.

Dereli, E . (2016). Öğretmen -çocuk ilişkisinin okul öncesi dönem çocuklarin sosyal yetkinlik ve davranişlari, sosyal problem çözme becerilerini yordayici etkisinin incelenmesi. Mehmet Akif Ersoy Üniversitesi Eğitim Fakültesi Dergisi, 1 (40) , 70-87. Retrieved from https://dergipark.org.tr/en/pub/maeuefd/issue/26849/282354

Dinçer, Ç., Baş, T., Teke, N., Aydın, E., İpek, S. ve Göktaş, İ. (2019). Okul öncesi dönem çocuklarının kişilerarası problem çözme ve sosyal becerileri ile akran ilişkilerinin değerlendirilmesi. Bolu Abant İzzet Baysal Üniversitesi Eğitim Fakültesi Dergisi, 19(3), 882-900.

Donohue, K. M., Perry, K. E., \& Weinstein, R. S. (2003). Teachers' classroom practices and children's rejection by their peers. Journal of Applied Developmental Psychology, 24(1), 91-118.

Ergene, T., Demirtaş-Zorbaz, S., Kurt, D. G., ve Ozer, A. (2018). Çocuk davranış ölçeğinin Türkçe’ye uyarlanmas1. Elementary Education Online, 17(4), 1960-1971.

Erol, A. ve Gülay Ogelman, H. (2020). Çocukların saldırganlık ve akran şiddetine maruz kalma düzeylerinin akranları tarafından sevilme düzeyleri üzerindeki yordayıcı etkisinin incelenmesi. Adnan Menderes Üniversitesi Ĕ̆itim Fakültesi Eğitim Bilimleri Dergisi, 11(1), 14-21.

Godleski, S. A., Kamper, K. E., Ostrov, J. M., Hart, E. J., \& Blakely-McClure, S. J. (2015). Peer victimization and peer rejection during early childhood. Journal of Clinical Child \& Adolescent Psychology, 44(3), 380-392.

Gunnar, M. R., Sebanc, A. M., Tout, K., Donzella, B., \& Van Dulmen, M. M. (2003). Peer rejection, temperament, and cortisol activity in preschoolers. Developmental Psychobiology: The Journal of the International Society for Developmental Psychobiology, 43(4), 346-368.

Güder, S. Y., Alabay, E. ve Güner, E. (2018). Okul öncesi öğretmenlerinin siniflarinda karșilaștiklari davraniș problemleri ve kullandiklari stratejiler, Illkögretim Online, 17 (1), 414-430.

Gülay Ogelman H. ve Ersan, C. (2014). Okul öncesi öğretmenlerinin sınıf yönetimi stratejilerinin çocukların akran ilişkileri üzerindeki etkisi. Bartın University Journal of Faculty of Education, 3(2) , 63-84

Gülay, H . (2009). Okul öncesi dönemde akran ilişkiler. Balıkesir Üniversitesi Sosyal Bilimler Enstitüsü Dergisi, 12 (22), 82-93

Hughes, J. N., Zhang, D., \& Hill, C. R. (2006). Peer assessments of normative and individual teacher-student support predict social acceptance and engagement among low-achieving children. Journal of School Psychology, 43(6), 447-463.

Ladd, G. W. (2010). The child behavior scale: applications and research findings. Parkview Publications.

Ladd, G. W. ve Profilet, S. M. (1996). The Child Behavior Scale: A teacher-report measure of young children's aggressive, withdrawn, and prosocial behaviors. Developmental Psychology, 32(6), 1008-1024. 
Menting, B., Van Lier, P. A., \& Koot, H. M. (2011). Language skills, peer rejection, and the development of externalizing behavior from kindergarten to fourth grade. Journal of Child Psychology and Psychiatry, 52(1), 7279.

Mercer, S. H., \& DeRosier, M. E. (2008). Teacher preference, peer rejection, and student aggression: A prospective study of transactional influence and independent contributions to emotional adjustment and grades. Journal of School Psychology, 46(6), 661-685.

Olson, S. L. (1992). Development of conduct problems and peer rejection in preschool children: A social systems analysis. Journal of Abnormal Child Psychology, 20(3), 327-350.

Salı, G. (2014). Okulöncesi dönem çocuklarında akran ilişkilerinin ve akran şiddetine maruz kalmanın çeşitli değişkenler açısından incelenmesi. Çukurova Üniversitesi Eğitim Fakültesi Dergisi, 43(2), 195-216.

Sandstrom, M. J., \& Coie, J. D. (1999). A developmental perspective on peer rejection: Mechanisms of stability and change. Child Development, 70(4), 955-966.

Sebanc, A. M. (2003). The friendship features of preschool children: Links with prosocial behavior and aggression. Social development, 12(2), 249-268.

Solak Arabacı, M. ve Demircioğlu, H. (2019). 5-6 yaş grubu çocukların akran ilişkilerinin incelenmesi. Yaşam Becerileri Psikoloji Dergisi, 3(6), 205-221.

Tabachnick, B.G. \& Fidell, L.S. (2007). Using multivariate statistics (5th ed.). Pearson Education.

Trentacosta, C. J., \& Shaw, D. S. (2009). Emotional self-regulation, peer rejection, and antisocial behavior: Developmental associations from early childhood to early adolescence. Journal of Applied Developmental Psychology, 30(3), 356-365.

Uzmen, S., ve Mağden, D. (2002). Okulöncesi eğitim kurumlarına devam eden altı yaş çocuklarının prososyal davranışlarının resimli çocuk kitapları ile desteklenmesi. M. Ü. Atatürk Eğitim Fakültesi Eğitim Bilimleri Dergisi, $15,193-212$.

Wang, M., Wang, J., Deng, X., \& Chen, W. (2019). Why are empathic children more liked by peers? The mediating roles of prosocial and aggressive behaviors. Personality and Individual Differences, 144, 19-23.

Wood, J. J., Cowan, P. A., \& Baker, B. L. (2002). Behavior problems and peer rejection in preschool boys and girls. The Journal of Genetic Psychology, 163(1), 72-88.

Wood, J. J., Emmerson, N. A., \& Cowan, P. A. (2004). Is early attachment security carried forward into relationships with preschool peers?. British Journal of Developmental Psychology, 22(2), 245-253.

Yalçıntaş Sezgin, E . (2018). Okulöncesi öğretmenlerin akran zorbalığı ilişkin algı ve görüşleri: Zorbalık davranışları tespitleri, zorbalık davranışları karşısında uyguladıkları stratejiler ve aldıkları önlemler. Pamukkale Üniversitesi Sosyal Bilimler Enstitüsü Dergisi, 33(1), 85-104. 